\title{
ANALISIS KEPUASAN RUMAH TANGGA PENERIMA RASKIN DI KABUPATEN TABANAN
}

\author{
Analysis of Raskin Household Satisfaction \\ In Tabanan District
}

\section{Ni Wayan Putu Artini, Joko Daryanto}

Program Studi Agribisnis, Fakultas Pertanian Universitas Udayana, Bali, Indonesia

E-mail : putuartini@unud.ac.id

\begin{abstract}
This study was conducted to determine the level of satisfaction of Raskin beneficiary households (RTS) toward Raskin Program and determine the gap between RTS expectations and Raskin Program performance for each satisfaction attribute. By collecting data from 60 respondens of legal beneficiaries, the primary data is processed using descriptive and survey method through questionaires and interviews and gathered using convenience sampling (random sampling). The method of IPA (importance performance analysis) and CSI (customer satisfaction index) with 24 variables was used in this study. The results showed that RTS satisfaction with the management of the Raskin program in Tabanan Regency was included in the category of satisfaction, and an important attribute that was not in accordance with the wishes of the RTS was the amount and quality of rice. To improve the effectiveness of Raskin, it is done by ranking the most urgent priority indicator variables to be immediately followed up as a service strategy for the Raskin program.
\end{abstract}

Keywords: raskin, household beneficiaries satisfaction, customer satisfaction index and importance performan analysis

\begin{abstract}
ABSTRAK
Penelitian ini dilakukan untuk mengetahui tingkat kepuasan rumah tangga penerima manfaat Raskin (RTS) terhadap Program Raskin dan menentukan kesenjangan antara harapan RTS dengan kinerja Program Raskin untuk setiap atribut kepuasan. Data primer diperoleh dari 60 responden penerima manfaat Raskin melalui kuesioner dan wawancara. Penentuan responden secara acak sederhana. Metode analisis IPA (importance performan analysis) dan CSI (customer satisfaction index) dengan 24 variabel digunakan dalam penelitian ini. Hasil penelitian memperlihatkan bahwa kepuasan RTS terhadap pengelolaan program Raskin di Kabupaten Tabanan termasuk dalam kategori puas, dan atribut penting yang belum sesuai dengan keinginan RTS adalah jumlah dan mutu beras. Untuk meningkatkan efektivitas Raskin, dilakukan dengan pemeringkatan variable indicator prioritas yang paling urgent untuk segera ditindaklanjuti sebagai strategi pelayanan Program Raskin.
\end{abstract}

Kata kunci: raskin, rumah tangga penerima manfaat, customer satisfaction index dan importance performan analysis

\section{PENDAHULUAN}

Pangan terutama beras di Indonesia merupakan bahan makanan pokok penduduk yang harus dipenuhi untuk mempertahankan hidupnya. Ketahanan pangan dalam Undang-Undang Nomor 7 tahun 1996 diartikan sebagai kondisi terpenuhinya pangan yang cukup, baik jumlah maupun mutunya, aman, merata, dan terjangkau oleh masyarakat.

Sejarah mencatat bahwa masalah pangan erat kaitannya dengan ketahanan sosial, stabilitas ekonomi, stabilitas politik dan keamanan atau ketahanan nasional secara keseluruhan. Kelemahan dalam mewujudkan ketahanan pangan akan menggoyahkan sendi-sendi ketahanan nasional. Oleh karena itu, pembangunan sistem ketahanan pangan nasional yang mantap menjadi syarat mutlak bagi pembangunan nasional.

Di Indonesia, masalah pangan dan ketahanan pangan tidak dapat dilepaskan dari komoditas beras. Hal ini karena beras merupakan bahan pangan pokok yang dikonsumsi oleh seluruh rakyat Indonesia. Beras merupakan komoditas utama dalam perekonomian Indonesia. Kekurangan beras dianggap sebagai ancaman terhadap kestabilan ekonomi dan politik (Baharsyah et al.,1998). Selanjutnya Timmer (1996) menyatakan perekonomian beras merupakan pendukung pesatnya pertumbuhan ekonomi Indonesia sejak tahun 1960. Selanjutnya Kasryno dan Pasandaran (2004) menyatakan bahwa kebijakan pembangunan pertanian selalu didominasi oleh kebijakan perberasan.

Untuk menjaga ketahanan pangan nasional pemerintah menugaskan Bulog (Badan Urusan Logistik) sebagai Badan Usaha Milik Negara yng mempunyai kontribusi besar dalam menjaga ketahanan pangan nasional. Bulog menjaga stabilitas harga beras di tingkat produsen maupun konsumen. Selain itu, pemerintah menugaskan Bulog untuk menjalankan suatu program yaitu program Raskin (beras miskin) untuk membantu masyarakat yang 
miskin.

Raskin merupakan subsidi pangan dalam bentuk beras yang diperuntukkan bagi masyarakat berpenghasilan rendah sebagai upaya dari pemerintah untuk meningkatkan ketahanan pangan dan memberikan perlindungan sosial pada masyarakat Program ini berlanjut hingga sekarang dengan tujuan mengurangi beban masyarakat melalui penenuhan kebutuhan pokok dalam bentuk beras. Raskin juga bertujuan meningkatkan akses pangan masyarakat melalui penjualan beras kepada msyarakat miskin. Melalui program ini pemerintah memberikan bantuan kepada masyarakat untuk mendapatkan hak atas pangan.

Melalui program Raskin, setiap RTS-PM (rumah tangga sasaran penerima manfaat) dapat membeli sejumlah beras di titik distribusi dengan harga yang lebih murah dari harga di pasar (subsidi). Harga beras bersubsidi yang harus dibayar RTS-PM sebesar Rp 1.600 per kg. dengan frekuensi distribusi rata-rata satu kali setiap bulan (BULOG, 2012). Program Raskin perlu dilaksanakan agar masyarakat miskin benar-benar bisa merasakan manfaatnya, yakni dapat membeli beras berkualitas baik dengan harga terjangkau, dengan tujuan agar lebih dapat tepat sasaran.

Proses penyaluran Raskin di Kabuapen Tabanan dimulai dari pengajuan SPA (Surat Permohonan Alokasi) oleh Bupati/walikota kepada Bulog berdasarkan rekap rumah tangga sasaran penerima manfaat (RTS-PM) di masingmasing kecamatan dan desa/kelurahan.

Berdasarkan SPA tersebut Bulog menerbitkan SPPB (Surat Perintah Penyerahan Beras) kepada SATKER (Satuan Kerja) Raskin untuk menyerahkan beras kepada kecamatan/ desa/kelurahan.. Berdasarkan SPPB tersebut SATKER Raskin menyerahkan beras Raskin ke petugas pelaksana distribusi desa/kecamatan.

Pelaksana distribusi desa/kecamatan menyerahkan atau menjual beras kepada rumah tangga miskin penerima manfaat (RTS-PM) yang memegang kartu Raskin. Penyerahan beras dititik distribusi dituangkan dalam berita acara serah terima (BAST) yang ditandatangani oleh SATKER Raskin dan pelaksana distribusi yang menerima beras Raskin serta diketahui oleh kepala desa/lurah/camat atau pejabat yang mewakili.

Keberhasilan pelaksanaan Program Raskin didasarkan atas enam indikator yang terdiri dari tepat sasaran, jumlah, harga, waktu, administrasi dan kualitas. Ketepatan sasaran penerima manfaat didasarkan pada data Rumah Tangga Sasaran (RTS) yang ada di tingkat desa/kelurahan. Ketepatan jumlah dipersepsikan RTS berdasarkan jumlah beras yang diterima RTS setiap bulannya. Ketepatan harga terjadi apabila harga yang dibayarkan RTS sebesar Rp 1600/kg di titik distribusi. Indikator tepat waktu diukur dari ketepatan waktu pengiriman beras antar bulan. Ketepatan kualitas adalah beras yang didistribusikan kepada RTS sesuai dengan standar kualitas beras yang telah ditetapkan . Dan tepat administrasi lebih banyak terkait dengan pelaksanaan di lapangan (Satker).
Kepuasan RTS dinilai dari perbandingan kinerja panitia Raskin selama ini dengan harapan mereka terhadap Raskin. Diantara kinerja dan harapan tersebut diperoleh informasi yang memiliki kemungkinan terjadinya kesenjangan (gap). Kesenjangan ini akan menimbulkan ketidakpuasan RTS dan penilaiaan yang negatif terhadap program secara keseluruhan. Oleh karena itu, informasi tentang kepuasan RTS akan sangat bermanfaat sebagai masukan bagi peningkatan pelayanan Raskin di masa yang akan datang khususnya di Kabupaten Tabanan sebagai lumbung beras di Provinsi Bali. Berdasarkan uraian di atas perlu dilakukan penelitian "Analisis Kepuasan Rumah Tangga Penerima Raskin di Kabupaten Tabanan"

\section{Perumusan Masalah}

Bedasarkan latar belakang tersebut, dapat dirumuskan permasalahan sebagai berikut.

1. Bagaimanakah tingkat kepuasan masyarakat penerima Raskin (RTS) terhadap pelaksanaan Program Raskin di Kabupaten Tabanan?

2. Bagaimanakah tingkat kinerja dan harapan RTS terhadap pelaksanaan Program Raskin dan kesenjangan diantara keduanya selama ini?

3. Bagaimana strategi peningkatan kepuasan RTS terhadap Program Raskin?

\section{METODE PENELITIAN}

\section{Lokasi Penelitian}

Penelitian ini dilakukan di Kabupaten Tabanan yaitu Desa Belimbing (Kecamatan Pupuan), Desa Bangli (Kecamatan Baturiti), dan Desa Nyitdah (Kecamatan Kediri). Pemilihan lokasi ini dilakukan secara Purposive yaitu pemilihan lokasi dilakukan secara sengaja dengan pertimbangan-pertimbangan tertentu. Adapaun yang dijadikan pertimbangan antara lain:

1. Kabupaten Tabanan merupakan kabupaten yang mempunyai tim koordinasi pembinaan Raskin dengan motto "BERAS GAPAT" (Bekerja Keras dan Gerak Cepat), namun masih ada penyimpangan dalam penyaluran Raskin.

2. Kecamatan yang terpilih ( Kecamatam Pupuan, Baturiti, dan Kediri) merupakan penerima manfaat Raskin paling banyak di Kabuaten Tabanan.

3. Desa terpilih (Desa Belimbing, Bangli, dan Nyitdah) merupakan penerima manfaat Raskin paling banyak di kecamatan terpilih.

\section{Populasi dan Sampel}

Populasi adalah wilayah generalisasi yang terdiri atas obyek/subyek yang mempunyai kuantitas dan karakterisitik tertentu yang ditetapkan oleh peneliti untuk dipelajari dan kemudian ditarik kesimpulannya, sementara sampel adalah sebagian dari jumlah dan karakteristik yang dimiliki oleh populasi tersebut (Sugiyono: 1998).

Populasi dalam penelitian ini adalah semua masyarakat penerima Raskin di Desa Belimbing, Desa Bangli, dan desa Nyitdah Jumlah populasi 1.341 orang. Sampel dalam penelitian diambil sebanyak 60 orang dengan mengacu pada teori Sugiarto (2001). Pemilihan sampel 
dilakukan secara acak (random sampling) artinya setiap rumah tangga miskin mempunyai kesempatan yang sama untuk diwawancarai.

\section{Jenis Data dan Sumber Data}

Data yang dikumpulkan dalam penelitian ini adalah data kualitatif dan kuantitatf. Data kualitatif dalam penelitian ini berupa data mengenai proses atau mekanisme penyaluran program Raskin dan permasalahan yang ada dalam proses penyaluran di Kabupaten Tabanan. Data kuantitatif berupa data karakteristik responden seperti umur, pendidikan, tanggungan keluarga, pengasilan ,jumlah beras yang diterima, harga beras yang dibayar oleh RTS, Jumlah penerima Raskin, dan sebagainya. Sumber data dalam penelitian ini adalah data primer dan data sekunder. Data primer diperoleh langsung dari responden memakai kuesioner yang dipersiapkan sebelumnya (Singarimbun dan Handayani, 1982). Data sekunder diperoleh dari instansi terkait seperti BULOG, BPS, hasil penelitian, dan sebagainya.

\section{Metode Pengumpulan Data}

Dalam penelitian ini pengumpulan dilakukan dengan tiga metode yaitu:

1. Survey; yaitu pengumpulan data dilakukan melalui wawancara langsung kepada responden dengan menggunakan daftar pertanyaan (kuesioner) yang dipersiapkan sebelumnya. (Singarimbun dan Handayani, 1982).

2. Observasi; yaitu merupakan cara pengumpulan data dengan cara pengamatan langsung ke tempat penyaluran Raskin dengan harapan dapat memperoleh gambaran secara jelas tentang proses penyaluran Raskin di Kabupaten Tabanan.

3. Wawancara Mendalam (Depth Interview); yaitu mencari data dengan cara wawancarai sejumlah responden kunci dengan memakai pedoman wawancara (Interview Guide). Metode ini dipakai untuk melengkapi data yang diperoleh dari survey dan observasi.

\section{Metode Analisis Data}

Metode yang digunakan dalam penelitian ini adalah metode deskriptif-kuantitatif. Metode kuantitatif yang digunakan adalah statistik deskriptif untuk mendeskripsikan gejala sosial yang berkaitan dengan kepuasan masyarakat atau rumah tangga di Kabupaten Tabanan.

Penelitian ini menggunakan variabel sebanyak 24 (X1 hingga X24). Variabel indikator itu dikelompokkan berdasarkan dimensi tangibles, reliability, responsiveness, assurance, dan emphaty, seperti pada Tabel 1.

Untuk mengetahui harapan dan penilaian kinerja, kepada responden diajukan pertanyaan-pertanyaan sub indikator dari setiap dimensi penilaian Raskin. Setiap dimensi diukur dalam veriabel yang dijabarkan kembali dalam indikator pertanyaan, dan dalam setiap pertanyaan dibuatkan skala $1-4$ untuk jawabannya.
Untuk membahas analisis persepsi RTS terhadap program Raskin terdapat dua variabel yang harus diukur yaitu variabel kinerja dan variable harapan sehingga diketahui kesenjangan yang terjadi. Semakin besar perbedaan nilai, semakin tidak efektif pelaksanaan program dan sebaliknya. Dalam setiap indikator diberikan skala nilai (skor), mulai $1=$ sangat tidak setuju, $2=$ tidak setuju, $3=$ setuju dan $4=$ sangat setuju. RTS diminta untuk memberikan nilai antara 1 4 untuk setiap pertanyaan sub indikator yang diajukan.

Importance Performance Analysis (IPA) merupakan salah satu alat analisis yang mengukur sejauh mana tingkat kepuasan pelanggan terhadap kinerja yang diberikan oleh kegiatan program Raskin. Atau sering juga disebut dengan analisis tingkat kepentingan dan kepuasan pelanggan. Metode IPA pertama kali diperkenalkan oleh Martilla and James (1977) dengan tujuan untuk mengukur hubungan antara persepsi konsumen dan prioritas peningkatan kualitas produk/jasa yang dikenal pula sebagai quadran analysis. IPA mempunyai fungsi utama untuk menampilkan informasi berkaitan dengan faktor-faktor pelayanan yang menurut konsumen sangat mempengaruhi kepuasan dan faktor-faktor pelayanan yang menurut konsumen perlu ditingkatkan karena kondisi saat ini belum memuaskan.

Skor kinerja dan kepentingan digunakan sebagai koordinat untuk memplotkan variabel indikator individu pada matriks dua dimensi yang ditunjukkan pada diagram kartesius.

Diagram kartesius merupakan suatu bagan yang dibagi atas empat bagian yang dibatasi oleh dua buah garis yang berpotongan tegak lurus pada titik-titik $(\mathrm{X}, \mathrm{Y})$. X merupakan rata-rata skor tingkat kepuasan (performance) responden terhadap variabel indikator dan $\mathrm{Y}$ adalah rata-rata dari skor tingkat harapan (importance) responden dari variabel indikator mempengaruhi kepuasan pelanggan.

Kuadran I menunjukkan variabel indikator yang mempunyai tingkat harapan diatas rata-rata dan skor kinerja dibawah rata-rata. Kuadran II menunjukkan variable yang mempunyai tingkat harapan dan kinerja diatas rata-rata. Kuadran III menunjukkan variable yang mempunyai tingkat harapan dengan kinerja dibawah ratarata. Kuadran IV menunjukkan faktor yang mempunyai harapan dibawah rata-rata tetapi sudah berkinerja diatas rata-rata.

Tabel 1. Variabel dalam Penelitian

\begin{tabular}{|l|c|}
\hline \multicolumn{1}{|c|}{ Atribut } & Simbul \\
\hline Dimensi Tangibles & $\mathrm{X} 1$ \\
\hline Jumlah petugas & $\mathrm{X} 2$ \\
\hline Ketersediaan jadwal & $\mathrm{X} 3$ \\
\hline Ketersediaan alat timbang & $\mathrm{X} 4$ \\
\hline Petugas pengecek kualitas & $\mathrm{X} 5$ \\
\hline $\begin{array}{l}\text { Tempat menyimpan sisa beras yang } \\
\text { belum ditebus }\end{array}$ & $\mathrm{X} 6$ \\
\hline $\begin{array}{l}\text { Jumlah beras telah sesuai dengan alokasi } \\
\text { RTS }\end{array}$ & $\mathrm{X} 7$ \\
\hline Dimensi Reliability \\
\hline RTM dan petugas saling kenal \\
\hline
\end{tabular}




\begin{tabular}{|c|c|}
\hline $\begin{array}{l}\text { Tim raskin kecamatan ikut memantau } \\
\text { raskin kelurahan }\end{array}$ & $\mathrm{X} 8$ \\
\hline $\begin{array}{l}\text { Pelayanan petugas di kelurahan telah } \\
\text { sesuai dengan keinginan RTS }\end{array}$ & $\mathrm{X} 19$ \\
\hline $\begin{array}{lcc}\text { Penetapan } & \text { RTS sebagai } & \text { penerima } \\
\text { manfaat melalui musyawarah } & \end{array}$ & $\mathrm{X} 10$ \\
\hline Dimensi Responsiveness & $\mathrm{X} 11$ \\
\hline $\begin{array}{l}\text { Petugas sudah tahu ada Program Raskin } \\
\text { sejak awal }\end{array}$ & $\mathrm{X} 12$ \\
\hline $\begin{array}{l}\text { Petugas siap memberi informasi kepada } \\
\text { RTS apabila diperlukan }\end{array}$ & $\mathrm{X} 13$ \\
\hline $\begin{array}{l}\text { Petugas sigap menanggapi keluhan RTS } \\
\text { dan masyarakat }\end{array}$ & $\mathrm{X} 14$ \\
\hline $\begin{array}{l}\text { Petugas siap mengganti beras berkualitas } \\
\text { jelek atau beratnya kurang }\end{array}$ & $\mathrm{X} 15$ \\
\hline \multicolumn{2}{|l|}{ Dimensi Assurance } \\
\hline $\begin{array}{l}\text { RTM yakin pemerintah menyediakan } \\
\text { Raskin tiap tahun }\end{array}$ & $\mathrm{X} 16$ \\
\hline $\begin{array}{l}\text { RTM yakin telah terdaftar sebagai } \\
\text { penerima Raskin }\end{array}$ & $\mathrm{X} 17$ \\
\hline $\begin{array}{lcc}\text { Pelaksana } & \text { telah memastikan } & \text { harga } \\
\text { Raskin Rp } 1.600 / \mathrm{kg} & & \\
\end{array}$ & $\mathrm{X} 18$ \\
\hline $\begin{array}{lrrr}\text { Jaminan keamanan } & \text { pada } & \text { saat } \\
\text { pendistribusian Raskin }\end{array}$ & $\mathrm{X} 19$ \\
\hline $\begin{array}{l}\text { Jaminan kelancaran pengantaran bers } \\
\text { setiap bulan }\end{array}$ & $\mathrm{X} 20$ \\
\hline \multicolumn{2}{|l|}{ Dimensi Emphaty } \\
\hline $\begin{array}{l}\text { Kesediaan petugas memahami keinginan } \\
\text { RTS }\end{array}$ & $\mathrm{X} 21$ \\
\hline $\begin{array}{l}\text { Petugas melibatkan tokoh masyarakat } \\
\text { dalam program Raskin }\end{array}$ & $\mathrm{X} 22$ \\
\hline $\begin{array}{l}\text { Petugas melibatkan PKK, Karang Taruna } \\
\text { dan Posyandu dalam mendistribusikan } \\
\text { Raskin }\end{array}$ & $\mathrm{X} 23$ \\
\hline $\begin{array}{llll}\begin{array}{l}\text { Petugas melaksanakan tugas } \\
\text { aturan }\end{array} & \text { sesuai } \\
\end{array}$ & $\mathrm{X} 24$ \\
\hline
\end{tabular}

\begin{tabular}{|c|c|}
\hline $\begin{array}{c}\text { Kuadran I } \\
\text { Prioritas Utama }\end{array}$ & $\begin{array}{c}\text { Kuadran II } \\
\text { Pertahankan Prestasi }\end{array}$ \\
\hline Kuadran III & KuadranIV \\
Prioritas Rendah & Berlebihan \\
\hline
\end{tabular}

Gambar 1. Diagram Kartesius

Dalam penentuan nilai harapan dan kinerja digunakan skala Likerts yang terdiri dari sangat tidak setuju, tidak setuju, setuju, dan sangat setuju. Keempat penilaian tersebut diberikan skor 1-4.

Berdasarkan hasil penilaian tingkat harapan dan kinerja maka diperoleh perhitungan mengenai kesesuaian antara keduanya. Tingkat kesesuaian adalah hasil perbandingan skor kinerja dengan skor harapan. Tingkat kesesuaian inilah yang akan menentukan urutan prioritas faktorfaktor yang mempengaruhi kepuasan RTS.

Customer Satisfication Index (CSI) merupakan indeks untuk menentukan tingkat kepuasan pelanggan secara menyeluruh dengan mempertimbangkan tingkat kepentingan dan tingkat kinerja dari atribut yang diukur. CSI dihitung dengan membagi weighted total dengan skala maksimum kemudian dikalilan 100. Rentang skala dan interpretasi Customer Satisfication Index (CSI) disajikan pada Tabel 2.

Tabel 2. Rentang skala dan interpretasi Customer Satisfication Index (CSI)

\begin{tabular}{cc}
\hline Skor & Interpretasi \\
\hline $24-42$ & Sangat tidak pua \\
$43-61$ & Puas \\
$62-80$ & Tidak puas \\
$81-100$ & Sangat tidak puas \\
\hline
\end{tabular}

\section{HASIL DAN PEMBAHASAN}

\section{Karakteristik Responden}

Dalam penelitian ini yang dijadikan sebagai responden adalah rumah tangga yang menerima manfaat Raskin di Kabupaten Tabanan tahun 2016. Karakteristik responden yang dijelaskan dalam penelitian ini antara lain umur, pekerjaan, pendidikan, tanggungan keluarga, dan penghasilan.

\section{Umur Responden}

Umur merupakan salah satu faktor yang menentukan produktivitas seseorang dalam bekerja. Dalam batas umur tertentu, semakin tinggi umur seseorang, makin tinggi produktivitasnya` Setelah mencapai umur tertentu, makin tinggi umur, makin rendah produktivitasnya karena menurunnya kemampuan fisik seseorang untuk bekerja. Jika dikaitkan dengan pengalaman, umumnya semakin tua umur biasanya mereka mempunyai pengalaman yang lebih banyak sehingga walaupun kondisi fisiknya turun, namun produktivitasnya bisa meningkat karena kemampuan daya nalarnya yang digunakan untuk bekerja.

Dari 60 orang responden yang diwawancarai 41 orang diantaranya berjenis kelamin laki-laki dan 19 orang berjenis kelamin perempuan. Umur response berkisar antara 30-80 tahun dengan rata-rata umur 47,17 tahun. Dilihat dari segi umur, semua responden berasa dalam usia kerja sehingga jika kondisi memungkinkan mereka masih potensial untuk bekerja.

\section{Pendidikan Responden}

Pendidikan merupakan salah satu faktor yang menentukan produktivitas. Makin tinggi pendidikan seseorang umumnya produktivitasnya makin tinggi. Pendikan yang memadai akan membuat seseorang lebih berani menanggung resiko, berfikir lebih rasional, berani transfer able dalam pekerjaan, berani menanggung resiko, dan sebagainya. Pedidikan responden di daerah penelitian bervariasi dari tidak tamat SD sampai dengan tamat Sekolah Lanjutan Tingkat Atas (SLTA). Mayoritas pendidikan formal responden adalah enam (6) tahun atau setara dengan tamat Sekolah Dasar (SD). Distribusi pendidikan responden disajikan pada Tabel 2. 
Tabel 2. Distribusi frekuensi tingkat pendidikan formal responden

\begin{tabular}{cccc}
\hline No & Pendidikan formal & $\begin{array}{c}\text { Jumlah } \\
\text { (orang) }\end{array}$ & Persen \\
\hline 1 & SD (tidak tamat) & 9 & 15,00 \\
2 & SD (Tamat) & 40 & 66,67 \\
3 & SMP (tamat) & 8 & 13,33 \\
4 & SLTA (tamat) & 3 & 5,00 \\
\hline & Total & 60 & 100,00 \\
\hline
\end{tabular}

Sumber: Analisis data primer

Dari Tabel 2 dapat disimpulkan bahwa tingkat pendidikan masyarakat yang menerima bantuan Raskin tergolong rendah, dimana mayoritas $(66,67 \%)$ berpendidikan setara dengan tamat SD. Ini berarti penyaluran program Raskin di Kabupaten Tabanan sesuai dengan yang ditetapkan yaitu yang berpendidikan rendah. Agar supaya masyarakat tidak dibelenggu oleh kemiskinan, maka perlu memperhatikan pendidikan masyarakat. Pendidikan merupakan salah satu alat pemutus lingkaran kemiskinan. Oleh karena itu perlu ada upaya peningkatan pendidikan dalam jangka panjang.

\section{Pekerjaan Responden}

Sumber penghasilan utama masyarakat bersumber dari pekerjaan. Rumah tangga penerima Raskin mempunyai pekerjaan pokok yang bervariasi. Yang dimaksud pekerjaan pokok dalam penelitian ini adalah pekerjaan yang prioritas penggunaan waktunya paling besar. Dari hasil wawancara diperoleh beberapa jenis pekerjaan pokok seperti petani, pedagang, buruh, kerajinan, dan sebagainya. Distribusi pekerjaan pokok responden disajikan pada Tabel 3.

Tabel 3. Distribusi frekuensi pekerjaan pokok

\begin{tabular}{cccc} 
Nosponden & & \\
\hline No & Jenis pekerjaan & $\begin{array}{c}\text { Jumlah } \\
\text { (orang) }\end{array}$ & Persen \\
\hline 1 & Petani & 38 & 63,33 \\
2 & Dagang & 6 & 10,00 \\
3 & Buruh & 10 & 16,67 \\
4 & Kerajinan & 3 & 5,00 \\
5 & Lain & 3 & 5,00 \\
\hline 6 & Total & 60 & 100,00 \\
\hline
\end{tabular}

Sumber: Analisis data primer

Dari Tabel 3 dapat dilihat bahwa masyarakat penerima Raskin adalah masyarakat yang kondisi ekonominya lemah. Hal ini dapat dilihat dari pekerjaan pokok mereka yang menerima Raskin mayoritas petani dan buruhtani. Dilihat dari pekerjaan responden tersebut, sudah sesuai dengan tujuan pemberian Raskin oleh pemerintah yaitu membantu masyarakat yang kurang mampu. Petani dan buruhtani umumnya adalah orang-orang yang berpenghasilan rendah.

\section{Anggota keluarga}

Jumlah anggota keluarga atau tanggungan keluarga akan menentukan besar kecilnya pengeluaran rumah tangga pada umumnya. Terdapat korelasi positif antara antara jumlah tanggungan dan pengeluaran. Secara demografis semakin besar tanggungan berarti ketergantungan semakin besar. Angka ketergantungan yang tinggi akan memperburuk keadaan ekonomi keluarga karena uang yang semestinya bisa diinvestasikan harus dikeluarkan untuk memenuhi kebutuhan anggota keluarga yang belum bekerja. Dari hasil penelitian ini diperoleh ratarata jumlah anggota keluarga penerima raskin 4 (empat) orang dengan kisaran 2-7 orang.

\section{Penghasilan}

Berdasarkan hasil penelitian rata-rata penghasilan masyarakat penerima Raskin Rp 584.170 per bulan dengan kisaran 200.000,00 - 2.000.000,00. Dengan ratarata jumlah anggota keluarga empat (4) orang, berarti penghasilan masyarakat Rp 146.042,5 per kapita. Angka ini sangatlah kecil sehingga dapatlah dikatakan mereka berada di bawah garis kemiskinan. Dari 60 orang yang diwawancarai ternyata terdapat 50 orang $(83,33 \%)$ responden yang pengeluarannya lebih besar dari penghasilannya seperti yang disajikan pada Tabel 4 .

Tabel 4. Distribusi responden bersadarkan penghasilan

\begin{tabular}{cccc}
\multicolumn{4}{c}{ dan pengeluaran } \\
\hline No & Uraian & $\begin{array}{l}\text { Jumlah } \\
\text { (orang) }\end{array}$ & Persen \\
\hline 1 & $\begin{array}{l}\text { Pengeluaran dan } \\
\text { penghasilan sama }\end{array}$ & 4 & 6,67 \\
2 & $\begin{array}{l}\text { Pengeluaran lebih } \\
\text { dari penghasilan } \\
\text { Pengeluaran kurang } \\
\text { dari penghasilan }\end{array}$ & 50 & 83,33 \\
Total & $\mathbf{6 0}$ & 10,00 \\
\hline
\end{tabular}

Sumber: Analisis data primer.

Dari Tabel 4 dapat dilihat hanya empat (4) orang saja yang pengeluarannya sama dengan penghasilan. Ini berarti dilihat dari aspek penghasilan/pengeluaran, ternyata masyarakat juga tergolong ekonomi lemah (miskin).

\section{Penilaian Responden}

Indikator yang dinilai oleh responden adalah kepentingan atau harapan masyarakat penerima Raskin dan kinerja kegiatan program Raskin yang terjadi di Kabupaten Tabanan.

\section{Kepentingan/harapan}

Responden menilai kepentingan atau harapan dari atribut kegiatan Raskin dengan menggunakan skor 1-4 dimana skor 1 untuk atribut yang sangat tidak penting dan skor 4 untuk atribut yang sangat penting. Dari hasil penelitian dapat dilihat bahwa atribut " jumlah beras yang dibagikan sesuai dengan kebutuhan RTS" (X6) memperoleh skor kepentingan yang paling tinggi. Ini berarti bahwa atribut tersebut paling penting yang mendapat perhatian bagi masyarakat penerima Raskin. Ini berarti bahwa masyarakat RTS menginginkan mendapat beras lebih dari $10 \mathrm{Kg}$ karena beras yang diperolehnya dirasakan masih kurang. Penilaian responden terhadap tingkat kepentingan atribut kegiatan Raskin disajikan pada Tabel 5 .

\section{Kinerja}


Responden menilai kinerja dari atribut kegiatan Raskin dengan menggunakan skor 1-4 dimana skor 1 untuk atribut yang sangat tidak penting dan skor 4 untuk atribut yang sangat penting. Dari hasil penelitian dapat dilihat bahwa atribut "Jaminan keamanan pada saat pendistribusian Raskin"kinerjanya tertinggi. Ini berarti bahwa pengelola program Raskin di Kabupaten Tabanan memberikan penekanan pada Jaminan keamanan pada

Tabel 5. Rata-rata skor penilaian responden terhadap kepentingan (harapan) dan kinerja atribut kegiatan Raskin

\begin{tabular}{clcc}
\hline No & \multicolumn{1}{c}{ Atribut } & Skor \\
& & RSH & RSK \\
\hline 1 & Jumlah petugas & 2,98 & 3,00 \\
2 & Ketersediaan jadwal & 3,00 & 3,00 \\
3 & Ketersediaan alat timbang & 2,20 & 2,20 \\
4 & Petugas pengecek kualitas beras & 3,12 & 2,90 \\
5 & Ada tempat menyimpan sisa beras yang belum ditebus & 2,77 & 2,80 \\
$\mathbf{6}$ & Jumlah beras yang dibagikan sesuai dengan kebutuhan RTS & $\mathbf{3 , 3 0}$ & 2,30 \\
7 & RTS dan petugas saling kenal & 3,00 & 3,00 \\
8 & Tim Raskin kec/kel ikut memantau pembagian Raskin & 2,70 & 2,60 \\
9 & Pelayanan petugas di kelurahan telah sesuai dengan keinginan RTS & 3,03 & 3,05 \\
10 & Penetapan RTS sebagai penerima Raskin telah melalui musyawarah & 2,70 & 2,30 \\
11 & Petugas membertahu ada program Raskin sejak awal & 3,07 & 3,03 \\
12 & Petugas siap memberi informasi kepada RTS apabila diperlukan & 3,20 & 3,18 \\
13 & Petugas menanggapi keluhan RTS dan masyarakat & 3,25 & 3,18 \\
14 & Petugas menanggapi saran dari RTS dan masyarakat & 3,22 & 3,20 \\
15 & Petugas siap mengganti beras berkualitas jelek/ beratnya kurang & 3,25 & 2,80 \\
16 & RTM yakin pemerintah menyediakan Raskin tiap tahun & 3,03 & 3,03 \\
17 & RTM telah terdaftar sebagai penerima Raskin yang sah & 3,03 & 3,03 \\
18 & Pelaksana telah memastikan harga Raskin Rp 1.600/kg & 3,10 & 3,10 \\
19 & Jaminan keamanan pada saat pendistribusian Raskin & 3,22 & $\mathbf{3 , 2 2}$ \\
20 & Jaminan kelancaran pengantaran beras setiap bulan & 3,20 & 3,00 \\
21 & Petugas memahami keinginan RTS & 3,10 & 3,10 \\
22 & Tokoh masyarakat dilibatkan dalam program Raskin & 2,90 & 2,98 \\
23 & Petugas melibatkan PKK/ Karang Taruna/Posyandu dalam mendistribusikan & $\mathbf{2 , 1 0}$ & $\mathbf{2 , 1 0}$ \\
& Raskin & & 3,20 \\
24 & Petugas telah melakukan tugas sesuai aturan & 71,6 & $\mathbf{7}$ \\
\hline & Total & $\mathbf{2 , 9 9}$ & $\mathbf{2 , 8 8}$ \\
\hline
\end{tabular}

Sumber: Diolah dari data primer

Berdasarkan Tabel 5 dapat dilihat bahwa rumah tangga sasaran (RTS) masih tidak puas dengan atribut keterlibatan PKK/karang taruna/Posyandu dalam pengelolaan karena RTS belum pernah merasakan kehadirannya dalam pengelolaan beras Raskin di daerah penelitian. Di samping itu, kepentingan/harapan RTS terhadap hal tersebut tidak signifikan. Dari Tabel tersebut dapat disimpulkan bahwa masih ada perbedaan antara kepentingan atau harapan RTS dan kinerja kegiatan program Raskin.

\section{Customer Satisfaction Index (CSI)}

Aritonang (2005) menyatakan bahwa kepuasan total pelanggan dapat diukur dengan menggunakan Customer Satisfaction Index (CSI). Customer Satisfacation Index dalam penelitian ini mengukur tingkat kepuasan RTS secara menyeluruh dengan saat pendistribusian Raskin. Aman yang dimaksudkan disini adalah : beras yang didistribusikan sesuai dengan jatah jumlah penerima RTS, saat pembagian Raskin berlangsung tertib, tidak terjadi kecemburuan sosial bagi yang tidak mendapat Raskin, dan sebagainya. Penilaian responden terhadap kinerja atribut kegiatan Raskin disajikan pada Tabel 5.

\section{Tabel 6. Perhitungan Customer Satisfaction Index ( CSI) kepuasan RTS di Kabupaten Tabanan}




\begin{tabular}{|c|c|c|c|c|c|}
\hline No & Atribut & RSH & WF & RSK & WS \\
\hline 1 & Jumlah petugas & 2,98 & 0,042 & 3,00 & 0,125 \\
\hline 2 & Ketersediaan jadwal & 3,00 & 0,042 & 3,00 & 0,126 \\
\hline 3 & Ketersediaan alat timbang & 2,20 & 0,031 & 2,20 & 0,068 \\
\hline 4 & Petugas pengecek kualitas beras & 3,12 & 0,044 & 2,90 & 0,126 \\
\hline 5 & $\begin{array}{l}\text { Ada tempat menyimpan sisa beras yang belum } \\
\text { ditebus }\end{array}$ & 2,77 & 0,039 & 2,80 & 0,108 \\
\hline 6 & $\begin{array}{l}\text { Jumlah beras yang dibagikan sesuai dengan } \\
\text { kebutuhan RTS }\end{array}$ & 3,30 & 0,046 & 2,30 & 0,106 \\
\hline 7 & RTS dan petugas saling kenal & 3,00 & 0,042 & 3,00 & 0,126 \\
\hline 8 & $\begin{array}{l}\text { Tim Raskin kec/kel ikut memantau pembagian } \\
\text { Raskin }\end{array}$ & 2,70 & 0,038 & 2,60 & 0,098 \\
\hline 9 & $\begin{array}{l}\text { Pelayanan petugas di kelurahan telah sesuai } \\
\text { dengan keinginan RTS }\end{array}$ & 3,03 & 0,042 & 3,05 & 0,129 \\
\hline 10 & $\begin{array}{l}\text { Penetapan RTS sebagai penerima Raskin telah } \\
\text { melalui musyawarah }\end{array}$ & 2,70 & 0,038 & 2,30 & 0,087 \\
\hline 11 & $\begin{array}{l}\text { Petugas membertahu ada program Raskin sejak } \\
\text { awal }\end{array}$ & 3,07 & 0,045 & 3,03 & 0,130 \\
\hline 12 & $\begin{array}{l}\text { Petugas siap memberi informasi kepada RTS } \\
\text { apabila diperlukan }\end{array}$ & 3,20 & 0,045 & 3,18 & 0,142 \\
\hline 13 & $\begin{array}{l}\begin{array}{l}\text { Petugas } \\
\text { masyarakat }\end{array} \\
\text { menanggapi keluhan }\end{array}$ & 3,25 & 0,045 & 3,18 & 0,144 \\
\hline 14 & $\begin{array}{l}\text { Petugas menanggapi saran dari RTS dan } \\
\text { masyarakat }\end{array}$ & 3,22 & 0,045 & 3,20 & 0,144 \\
\hline 15 & $\begin{array}{l}\text { Petugas siap mengganti beras berkualitas jelek/ } \\
\text { beratnya kurang }\end{array}$ & 3,25 & 0,042 & 2,80 & 0,127 \\
\hline 16 & $\begin{array}{l}\text { RTM yakin pemerintah menyediakan Raskin tiap } \\
\text { tahun }\end{array}$ & 3,03 & 0,042 & 3,03 & 0,128 \\
\hline 17 & $\begin{array}{l}\text { RTM telah terdaftar sebagai penerima Raskin } \\
\text { yang sah }\end{array}$ & 3,03 & 0,043 & 3,03 & 0,128 \\
\hline 18 & $\begin{array}{l}\text { Pelaksana telah memastikan harga Raskin Rp } \\
1.600 / \mathrm{kg}\end{array}$ & 3,10 & 0,045 & 3,10 & 0,134 \\
\hline 19 & $\begin{array}{l}\text { Jaminan keamanan pada saat pendistribusian } \\
\text { Raskin }\end{array}$ & 3,22 & 0,045 & 3,22 & 0,145 \\
\hline 20 & $\begin{array}{l}\text { Jaminan kelancaran pengantaran beras setiap } \\
\text { bulan }\end{array}$ & 3,20 & 0,043 & 3,00 & 0,134 \\
\hline 21 & Petugas memahami keinginan RTS & 3,10 & 0,040 & 3,10 & 0,134 \\
\hline 22 & $\begin{array}{l}\text { Tokoh masyarakat dilibatkan dalam program } \\
\text { Raskin }\end{array}$ & 2,90 & 0,029 & 2,98 & 0,121 \\
\hline 23 & $\begin{array}{l}\text { Petugas melibatkan PKK/ Karang } \\
\text { Taruna/Posyandu dalam mendistribusikan Raskin }\end{array}$ & 2,10 & 0,029 & 2,10 & 0,062 \\
\hline \multirow[t]{3}{*}{24} & Petugas telah melakukan tugas sesuai aturan & 3,20 & 0,045 & 3,10 & 0,138 \\
\hline & Total & 71,67 & 1,00 & 69,20 & 2,908 \\
\hline & Rata-rata & 2,99 & & $\mathbf{2 , 8 8}$ & $\mathbf{0 , 1 2 1}$ \\
\hline
\end{tabular}

Sumber: Dianalis dari data primer

Keterangan:

RSH : Rata-rata skor harapan

WF : Weighting Factor $(\mathrm{WF}=\mathrm{RSH} / 71,67$

RSK : Rata-rata skor kinerja

WS : Weighted Score (WS=RSKxWF)

Dari Tabel 6 dapat dilihat bahwa nilai Customer Satisfaction Index (CSI) sebesar 72,7\%. Ini berarti kepuasan masyarakat penerima Raskin di Kabupaten Tabanan terhadap pengelola program Raskin tergolong puas. Untuk selanjutnya perlu ada upayaupaya untuk meningkatkan tingkat kepuasan msyarakat RTS dengan cara meningkatkan kinerja pengelola program Raskin, terutama memperhatikan atribut-atribut yang skornya bernilai rendah seperti: Ketersediaan alat timbang, pengecekan kualitas beras, jumlah beras yang dibagikan sesuai dengan kebutuhan RTS, pemantauan pembagian Raskin oleh tim Raskin dari kel/kec, pergantian beras berkualitas jelek/ beratnya kurang, keterlibatan okoh masyarakat dalam program Raskin, dan keterlibatan PKK/ Karang Taruna/Posyandu dalam mendistribusikan Raskin.

\section{Importance Performance Analysis (IPA)}

Analisis Importance Performance Analysis (IPA) akan membantu pihak pengelola program Raskin untuk menentukan langkah untuk meningkatkan kepuasan masyarakat penerima Raskin. Analisis ini 
berupa dimensi-dimensi atribut yang mempengaruhi strategi peningkatan kepuasan masyarakat penerima Raskin. Data tingkat kepentingan dan tingkat kinerja dimasukkan kedalam kuadran yang terbagi menjadi empat (4) kuadran dengan bantuan aplikasi SPSS.

Kuadran I menunjukkan atribut-atribut yang dianggap penting bagi RTS tetapi belum sesuai dengan keinginan RTS. Dalam penelitian ini diperoleh atribut-atribut yang termasuk dalam kuadran I adalah jumlah beras yang dibagikan sesuai dengan kebutuhan RTS (X6) dan mengganti beras berkualitas jelek/ beratnya kurang (X15). Atributatribut ini harus mendapat perhatian khusus dari pengelola program Raskin dan merupakan prioritas utama bagi pengelola program Raskin.

Kuadran II menunjukkan atribut-atribut yang dianggap penting bagi RTS dan sesuai dengan keinginan RTS. Dalam penelitian ini diperoleh atribut-atribut yang yang termasuk dalam kuadran II adalah petugas mengecek kualitas beras (X4), RTS dan petugas saling kenal (X7), pelayanan petugas di kelurahan telah sesuai dengan keinginan RTS (X9), petugas memberitahu ada program Raskin sejak awal (X11), petugas siap memberi informasi kepada RTS apabila diperlukan (X12), petugas menanggapi keluhan RTS dan masyarakat (X13), petugas menanggapi saran dari RTS dan masyarakat (X14), pelaksana telah memastikan harga Raskin Rp 1.600/kg (X18) jaminan keamanan pada saat pendistribusian Raskin (X19) jaminan kelancaran pengantaran beras setiap bulan (X20), petugas memahami keinginan RTS (X21), dan petugas telah melakukan tugas sesuai aturan (X24). Atribut ini harus dipertahankan oleh pengelola program Raskin Kuadran III menunjukkan atribut-atribut yang dianggap kurang penting bagi pelayanan RTS dan kinerja pelaksana program Raskin juga kurang memadai. Dalam penelitian ini diperoleh atributatribut yang yang termasuk dalam kuadran III adalah ketersediaan alat timbang (X3) ada tempat menyimpan sisa beras yang belum ditebus (X5) tim Raskin kec/kel ikut memantau pembagian Raskin (X8), penetapan RTS sebagai penerima Raskin telah melalui musyawarah (X10) dan keterlibatan PKK/ Karang Taruna/Posyandu dalam mendistribusikan Raskin (X23). Atribut ini menjadi prioritas kedua bagi pengelola program Raskin.

Kuadran IV menunjukkan atribut-atribut yang dianggap kurang penting oleh RTS tetapi dijalankan dengan sangat baik oleh pengelola program Raskin. $\mathrm{Hal}$ ini dianggap berlebihan yang berarti pemborosan sumberdaya. Atribut yang terdapat dalam kuadran IV adalah Jumlah petugas (X1), Ketersediaan jadwal (X2) dan Tokoh masyarakat dilibatkan dalam program Raskin (X22). Gambar diagram Kartesius disajikan pada Gambar 2.

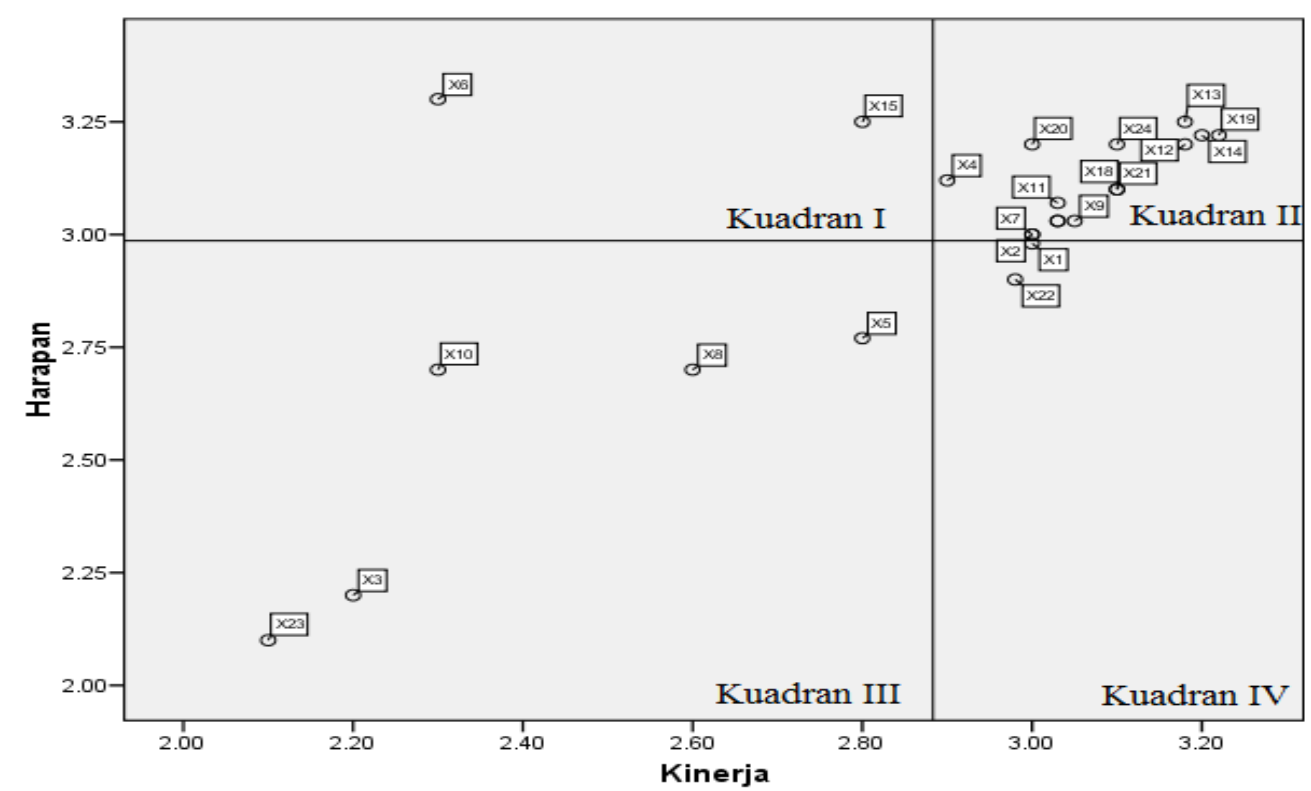

Gambar 2. Diagram Kartesius

\section{SIMPULAN DAN SARAN}

\section{Simpulan}

Berdasarkan hasil penelitian dan pembahasan sebelumnya maka dapat ditarik kesimpulan sebagai berikut:

1. Kepuasan RTS terhadap pengelolaan program Raskin di Kabupaten Tabanan termasuk dalam katagori puas dengan pencapaian indeks kepuasan sebesar 72,7\%

2. RTS di Kabupaten Tabanan merasakan adanya kesenjangan antara harapan/keinginan RTS dengan kinerja pelaksana program Raskin. Atribut-atribut yang dianggap penting oleh RTS ternyata belum sesuai dengan keinginan RTS adalah jumlah beras yang dibagikan sesuai dengan kebutuhan RTS (X6) dan mengganti beras berkualitas jelek/ beratnya kurang (X15). 
Atribut-atribut ini hendaknya merupakan prioritas utama bagi pengelola Raskin dan mendapat perhatian khusus.

3. Untuk meningkatkan kepuasan RTS, maka perlu uapaya untuk meningkatkan jumlah beras yang diperoleh individu, dan menjamin kualitas dan kuantitas beras yang diberikan kepada RTS.

\section{Saran}

Ada beberapa saran yang penting untuk diperhatikan dalam penelitian ini antara lain:

1. Pengelola program Raskin perlu memberikan prioritas perhatian terhadap atribut-atribut yang oleh rumah tangga sasaran (RTS) dianggap penting yaitu jumlah beras yang diberikan ke RTS ditingkatkan dan dijaga kualitas dan kuantitas.

2. Perlu ada penelitian lanjutan dengan wilayah yang lebih luas dan atribut yang lebih banyak untuk meneliti kepuasan rumah tangga sasaran (RTS).

\section{DAFTAR PUSTAKA}

Aritonang, R.L.2005. Kepuasan Pelanggan. Gramedia, Jakarta

Badan Urusan Logistik. 2011.Standar Operasional Prosedur Pengadaan Gabah/Beras Dalam Negeri di Lingkungan Perum BULOG 2011.

Badan Urusan Logistik. 2013 "Pedoman Umum Raskin”. Denpasar: Badan Urusan Logistik.

Badan Urusan Logistik. 2014. "Pedoman Umum Raskin”. Denpasar: Badan Urusan Logistik

Burhan.2005 Metode Penelitian Kuantitatif, http://repository.usu.ac.id/bitstream/12 3456789/20006/2/Reference.pdf.Jakarta Kencana,. (Diunduh pada tanggal 27 Agustus 2015).

Bulkin, Farchan, 1998, Kemiskinan dalam studi Politik Indonesia, Transformasi Seri III, Jakarta.

Depdagri, Permendagri, 2011. "skala dan klasifikasi pengukuran efektifitas kinerja instansi pemerintah".

Damanik, RF. 2014. "analisis efektivitas distribusi beras miskin (raskin)". http://download.portalgaruda.org/article . pdf. (Diunduh pada tanggal 14 juni 2015).

Durianto, D. Sugiarto, A.W. Widjaja dan Supratikno, H. 2003. Invasi Pasar dengan Iklan yang Efektif. Jakarta: PT Gramedia Pustaka Utama. (Diunduh pada tanggal 4 Nopember 2015).

Esmara, Hendra, 1986, Perencanaan dan Pembangunan di Indonesia, PT. Gramedia, Jakarta.
Frida, S.H. 2011. Efektifitas Pelaksanaan Raskin (Studi Kasus: Kelurahan VI Suku Kecamatan lubukSikarah Kota Solok) (Skripsi). Fakultas Pertanian Universitas Andalas, Padang. (Diunduh pada tanggal 27 Agustus 2015).

Effendi, Tajuddin Noer, 1993, Sumber Daya Manusia, Peluang Kerja dan Kemiskinan, Tiara

Handoko, T. Hani. 2001. Manajemen. PT BPFE. Yogyakarta.

Harianto, 2001. Pendapatan, Harga dan Konsumsi Beras. Dalam Bunga RampaiEkonomi Beras (Suryana, A. Dan S. Mardianto, 2001). Jakarta: LPEM FE-UI (Diunduh pada tanggal 27 Agustus 2015).

Hastuti, B.S. Sulton Mawardi. 2012. Tinjauan Efektivitas Pelaksanaan RASKIN Dalam Mencapai Enam Tepat. SMERU. Jakarta. (Diunduh pada tanggal 22 September 2015).

Herma, Y. 2011. Evaluasi Pelaksanaan Raskin Di Kota Semarang (Studi Kasus :Di KelurahanPedurungan Kidul) (Skripsi). Fakultas Pertanian Universitas Semarang. (Diunduh pada tanggal 27 Agustus 2015).Mahsun, M. 2006. Pengukuran Kinerja kefektifan. BPFE Yogyakarta. Yogyakarta. (Diunduh pada tanggal 27 Agustus 2015).

Kotler, P.1997. Manajemen Pemasaran: Analisis, Perencanaan, Implementasi dan Kontrol PT Prehelindo. Jakarta

Rihadini, M. 2012. "Konsep Efektifitas Pada Pelaksanaan Program Raskin"http://repository.unhas.ac.id/bitstream/han dle/123456789/1672/BAB\%20II.pdf. (Diunduh pada tanggal 27 Agustus 2015)

Maria, YSM. 2011."evaluasi pelaksanaan program beras miskin (raskin)". repository.usu.ac.id/bitstream/123456789/25443/5/ Chapter\%20I.pdf (Diunduh pada tanggal 14 juni 2015)

Musawa, Maryam. 2009. Studi Implementasi Program Beras Miskin (RASKIN) di wilayah Kelurahan Gajahmungkur Kecamatan gajahmungkur Kota Semarang. Jurusan Magister Administrasi Publik Program Studi Magister Ilmu Administrasi. Program Pascasarjana Universitas Diponegoro, Semarang. (Diunduh pada tanggal 22 September 2015)

Panjaya, YH. .2011. "evaluasi pelaksaan pendistribusian program raskin"http://eprints.undip.ac.id/33079/1/jurnal_yo ssy.pdf. (Diunduh pada tanggal 14 juni 2015)

Purwanto, EP. 2015. "pengertian distribusi Raskin". " http://repository.uin- 
suska.ac.id/1084/3/BAB\%20II.pdf. （ Diunduh pada tanggal 14 Agustus 2015)

Singarimbun, M dan Tri Handayani. 1982. Pembuatan Kuesioner, Metode Penelitian Survai. LP3ES, Jakarta.

SMERU. 2008. Efektifitas Pelaksanaan Raskin. SMERU Research Institute: Jakarta.http://www.smeru.or.id/sites/default/files/p ublication/raskin2008_ind.pdf. (Diunduh pada tanggal 4 Nopember 2015)
Sugiarto; Herlambang, Tedy; Brastoro; Sudjana, Rachmat; Kelana, Said. 2002. Ekonomi Mikro. Jakarta: PT. Gramedia Pustaka Utama. (Diunduh pada tanggal 4 Nopember 2015)

Supranto, J. 2012. Teknik sampling untuk survei dan eksperimen. Rineka cipta. Jakarta. (Diunduh pada tanggal 4 Nopember 2015).

Timmer, C.P. 1996. Does Bulog Stabilize Rice Price in Indonesia? Should it Try?. Bull. Indon.Econ.Studies 